\title{
CYP1A2*7 Allele
}

National Cancer Institute

\section{Source}

National Cancer Institute. CYP1A2*7 Allele. NCI Thesaurus. Code C46038.

Human CYP1A2*7 allele is located within $15 q 24$ and is approximately $8 \mathrm{~kb}$ in length. This allele, a variant form of the CYP1A2 wild-type allele, encodes cytochrome P450 1A2*7 protein. The CYP1A2*7 allele exhibits a clinically-relevant SNP (g.3534G>A) in the 5' splicesite consensus sequence of intron 6 that is predicted to result in abnormal mRNA splicing. This alteration decreases the in vivo enzymatic activity of the cytochrome P450 $1 \mathrm{~A} 2 * 7$ protein. 